\title{
Mobile Banking Satisfaction: An Empirical Research
}

\author{
Zuo Renshu1, a, * Li Hongming 2 , b \\ 1,2Marketing and E-commerce Department of Business School, Sichuan University, No. 29 \\ Wangjiang Road, Wuhou District, Chengdu, China \\ azuorenshu@126.com, *blihongming1927@163.com
}

Keywords: Mobile Banking, TAM, Satisfaction, Structural Equation Model

\begin{abstract}
With the development of mobile internet, mobile banking have been gaining a meaningful development and success. A lot of consumers use mobile banking to deal with banking affairs. Because that improves their performances startling. Based on Technology Acceptance Model (TAM), the author collected a sample of 265 people from 60 cities or 21 provinces to study mobile banking satisfaction in China. LISREL 8.70 is used to analyze the structural equation model (SEM), finding that $90 \%$ of variance can be explained by the model. That means the model constructed is appropriately. In additional, trust, perceived ease of use and perceived efficacy all have a strong positive effect on mobile banking satisfaction. Interestingly, perceived security only exerts a limited effect on satisfaction.
\end{abstract}

\section{Introduction}

Mobile banking is a newly kind of e-banking, which means dealing with banking business by wireless mobile terminals, for example: cell phone, personal digital assistant or even car. According to a report from iresearch ( a Chinese internet research company), saying that there are 301 million people have been using mobile banking, and every user will use mobile banking 17.5 times per month in 2014; the transaction scale reach to 3.28 billion in the same year [1]. Another report released by China Internet Network Information Center (CNNIC) shows that, we get 214.71 million people using mobile banking cell phone application by the June of 2015 [2]. That is an $8.4 \%$ increase compared to the data in December 2014. Consequently, identifying the influence factors of mobile banking satisfaction will enrich the theory and be useful to the banking industry practice.

\section{Literature Review and Research Hypothesis}

\subsection{Literature Review}

This paper studies the satisfaction of mobile banking, based on the theory of Technology Acceptance Model (TAM). There are three main variables adopting TAM that referring to Perceived Ease of Use (PEOU), Perceived Usefulness (PU) and Self-Efficacy (SEL). According to Pin \& Lin [3], SEL means self-assessment that whether consumers find they have necessary knowledge, skill and capabilities to use mobile banking. PEOU means that mobile banking should be easy to use and learn. PU means that consumers will feel mobile banking is useful. Meanwhile, security factors is proved to be a key element in e-commerce or mobile banking field [4-6]. In additional, trust (TRU) factor is always related with security factor. This paper use Perceived Security (PS) to measure security factor which is meaning that the security degree consumer perceived when use mobile 
banking to transform personnel information [7]. Lin \& Wang proved that trust is customer's belief to certain mobile banking vendor concerning them is upright, benign, capable and predictable [8].

\subsection{Research Hypothesis}

According to Luarn \& Lin [3], the increase of SEL will lead to the increase of PEOU and PU. At the same time, PEOU have a positive effect on PU. To \& Lai [5] found that lack of trust is a main obstacle to hind consumers use and assess mobile banking in China, meanwhile lack of trust is a result of PS. Besides, Kim et al. [9] think PS will have a positive effect on trust. Roca et al. [10] and Ponte et al. [11] both agree the same point. Lin \& Wang reckon that trust will influence satisfaction positively. According to Tsai's research [12] that PEOU and PU will have a positive effect on satisfaction.

Concerning these solid researches mentioned above, the author propose 8 hypothesizes below to construct the research model: H1: SEL have a positive effect on PEOU.H2: SEL have a positive effect on PU.H3: SEL have a positive effect on TRU.H4: PS have a positive effect on TRU.H5: PEOU have a positive effect on PU.H6: PEOU have a positive effect on SAT.H7: PU have a positive effect on SAT.H8: TRU have a positive effect on SAT.

\section{Data Collection Procedure}

The questionnaire is made up of 2 parts. Part 1 is the basic information of respondents, and part 2 is research model which adopted Likert scales (1-7), with anchors ranging from "strongly disagree" to "strongly agree" were used for all of questions from part 2. The questionnaire is delivered by Chinese famous social media WeChat. In order to identify qualified respondents, the first question required the subject to confirm whether have used mobile banking before. Only they confirm have used mobile banking were allowed to continue the answering procedure. All of the questions used in part 2 were adopted from previous research: PEOU and PU come from Luarn and Lin (2004), SAT and TRU come from Lin and Wang (2006), SEL comes from Gu et al. (2009), PS comes from Cheng et al. (2006).

The questionnaire was delivered by Chinese social media-WeChat, Sina-Microblog and QQ-Zone. Only these have used mobile banking is qualified for this research. 265 qualified samples were taken back. It could reach to 21 provinces or more than 60 cities. Sincerely appreciate to these people involved.

\section{Data Analysis}

\subsection{Descriptive Statistics}

265 valid questionnaires were retrieved in which 131 respondents is male. $82 \%$ of the respondent have bachelor degree or above. In total, only 35.09\% subjects is student in campus, the rest $64.91 \%$ is engaged in full-time jobs. Almost half of these respondents earn 3500 Yuan or above per month. It means the respondents has a balance gender proportion and get a guaranteed paycheck every month, which is an excellent sampling for the research of mobile banking satisfaction.

20 items of the questionnaire scored a mean ranging from 4.3 and 5.83 meaning that mobile banking satisfaction is not positive, as each item is measured by 1 to 7 . Furthermore, the items used to measure satisfaction scored 5.15, 5.20 and 5.06 respectively. It demonstrate that the satisfaction of mobile banking is waiting to be improved on the other hand. Especially, all of the 3 items used to measure perceived security are lower than 5 , meaning consumers feel unsafety to use mobile banking. 


\subsection{Measurement Model}

Measurement model is related to Confirmatory Factor Analysis in Structure Equation Model (SEM), which is tested by LISREL 8.70 in this paper. According to Wu (2010) [13] that DWLS should be adopted when the sampling data is small, complicated and high skewness. Consequently, this paper use DWLS to analyzing sampling data. 7 fitting indexes, Composite Reliability (CR.) and Average Variance Extracted (AVE.) are used to measure factor's reliability and validity. As is shown in Tab. 1 and Tab. 2, this research have a good fitting degree, appropriate reliability and convergence validity.

Tab. 1 Fitting Indexes

\begin{tabular}{|c|c|c|c|}
\hline $\begin{array}{c}\text { Fitting } \\
\text { Index }\end{array}$ & $\begin{array}{c}\text { Recommended } \\
\text { Value }\end{array}$ & $\begin{array}{c}\text { Measurement } \\
\text { Model }\end{array}$ & $\begin{array}{c}\text { Structural } \\
\text { Model }\end{array}$ \\
\hline$\chi^{2} /$ df & $\leq 3.00$ & 1.89 & 1.84 \\
\hline AGFI & $\geq 0.80$ & 0.99 & 0.99 \\
\hline NFI & $\geq 0.90$ & 0.98 & 0.98 \\
\hline NNFI & $\geq 0.90$ & 0.99 & 0.99 \\
\hline CFI & $\geq 0.90$ & 0.99 & 0.99 \\
\hline RFI & $\geq 0.90$ & 0.98 & 0.98 \\
\hline RMSEA & $\leq 0.08$ & 0.058 & 0.057 \\
\hline
\end{tabular}

Tab.2 CR and AVE

\begin{tabular}{|l|l|l|}
\hline Factor & CR. & AVE. \\
\hline 1.SEL & 0.80 & 0.57 \\
\hline 2.PS & 0.87 & 0.71 \\
\hline 3.PEOU & 0.86 & 0.68 \\
\hline 4.PU & 0.88 & 0.72 \\
\hline 5.TRU & 0.89 & 0.63 \\
\hline 6.SAT & 0.87 & 0.69 \\
\hline
\end{tabular}

\subsection{Structural Model}

It is found that the path coefficient of $\mathrm{H} 2$ is 0.11 ( $\mathrm{t}$ value is 0.40 ) and that of $\mathrm{H} 7$ is -0.04 ( $\mathrm{t}$ value is -0.09). That is to say, $\mathrm{H} 2$ and $\mathrm{H} 7$ is not significant in statistics. The rest of hypotheses are supported by the data. Properties of the modified causal path, including standardized path coefficients, $t$ values and explanation of variance for each equation in the hypothesized model are presented in Fig. 1. And the modified model have good fitting indexes: $\chi 2$ is 300.28 , df. is 163 , RMSEA $=0.056, \chi 2 / \mathrm{df}=1.84$, 90 Percent Confidence Interval for RMSEA $=(0.046 ; 0.066)$, P-Value for Test of Close Fit (RMSEA $<0.05)=0.14, \quad$ AGFI=0.99, NFI=0.98, NNFI=0.99, CFI=0.99, RFI=0.99. It demonstrated that structural model have a favorable fitting index. R2 of the endogenous variables are good, which is 0.9, $0.91,0.88$ and 0.95 for SAT, TRU, PEOU and PU respectively. It means structural model can explain $90 \%$ variance of mobile banking satisfaction. At last, the total effect of perceived security on satisfaction is $0.17=0.25 * 0.67(\mathrm{P}<0.001)$. The total effect of self-efficacy on satisfaction is $0.91=0.93 * 0.31+0.78 * 0.67(\mathrm{P}<0.001)$.

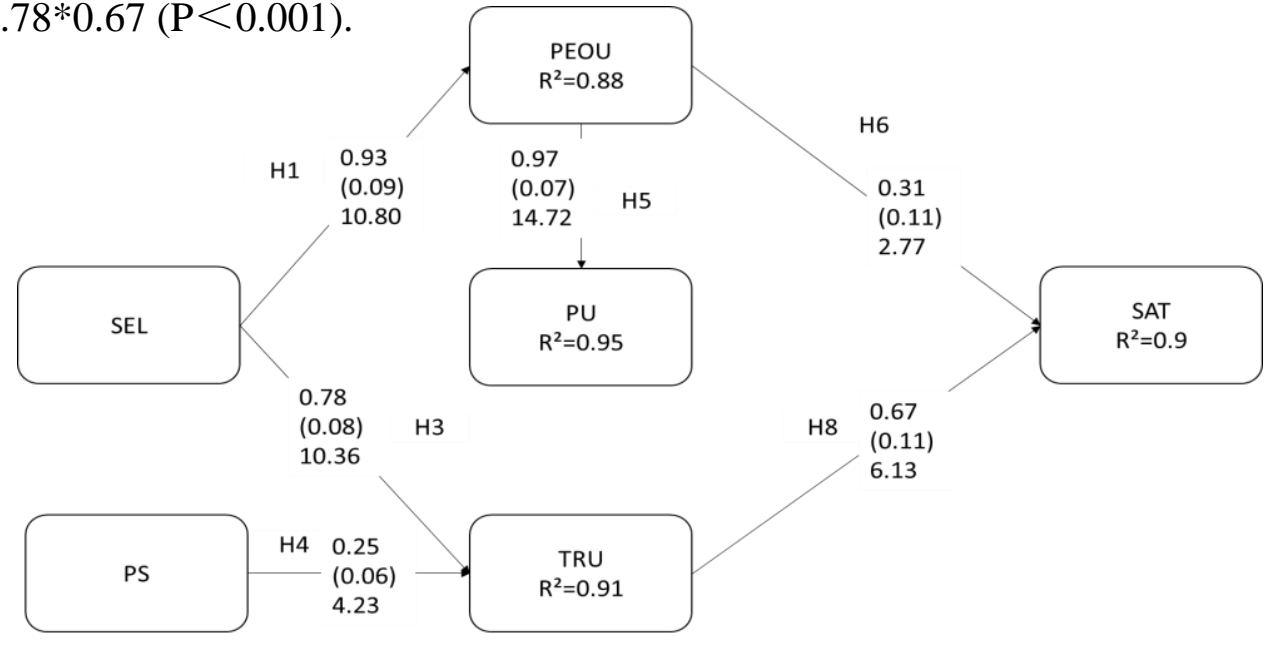

Fig. 1 Hypotheses testing results 


\section{Conclusion and Limitation}

The effect that perceived security exert on satisfaction in mobile banking is declined. Previous articles illustrated that perceived security is a key factor in mobile banking field, especially satisfaction. However, this paper found that the effect of perceived security on satisfaction is only 0.17 . In addition, the mean of perceived security is 4.51 , which means consumers think the security of mobile banking is negative. Consequently, perceived security is not an important factor in mobile banking satisfaction, but it still necessary in mobile banking field. So perceived security is necessary for mobile economy but helpless for improve the satisfaction of mobile banking.

Trust is the most important factor in mobile banking satisfaction. It tells us banks should emphasize trust when marketing their mobile banking. The more trust customer perceive, the more satisfaction mobile banking get.

PEOU has a direct effect on mobile banking satisfaction and the PU to mobile banking. That is to say, easy to use is a very crucial point in mobile banking functional product field.

This paper is useful in academic research and marketing practice of mobile banking. However, in order to make the model parsimony and understandable, certain variables have not taken into account yet, such as cultural, economic and aesthetics etc. Besides, we look forward to deepen research on mobile banking loyalty.

\section{References}

[1] 2015 Report on the trend of China's e-commerce industry chain [Z]. 2015: 2015.

[2] China Internet Network Information Center. 36th. statistical report on the development of the thirty-sixth China Internet Network [Z]. 2015: 2015.

[3] Luarn P, Lin H. Toward an understanding of the behavioral intention to use mobile banking[J]. Computers in Human Behavior, 2005,21(6):873-891.

[4] Kesharwani A, Bisht S S. The impact of trust and perceived risk on internet banking adoption in India[J]. International Journal of Bank Marketing, 2012, 4(30):303-322.

[5] To W, Lai L S L. Mobile Banking and Payment in China[J]. IT Professional, 2014,16(3):22-27.

[6] Laukkanen T. Internet vs mobile banking: comparing customer value perceptions[J]. Business Process Management Journal, 2007,6(13):788-797.

[7] Cheng T C E, Lam D Y C, Yeung A C L. Adoption of internet banking: An empirical study in Hong Kong[J]. Decision Support Systems, 2006,42(3):1558-1572.

[8] Lin H, Wang Y. An examination of the determinants of customer loyalty in mobile commerce contexts[J]. Information \& Management, 2006,43(3):271-282.

[9] Exploring Online Transaction Self-Efficacy in Trust Building in B2C E-Commerce[J]. Journal of Organizational and End User Computing, 2009,1(21):37-59.

[10] Roca J C, García J J, de la Vega J J. The importance of perceived trust, security and privacy in online trading systems[J]. Information Management \& Computer Security, 2009,2(17):96-113.

[11]Bonsón Ponte E, Carvajal-Trujillo E, Escobar-Rodríguez T. Influence of trust and perceived value on the intention to purchase travel online: Integrating the effects of assurance on trust antecedents[J]. Tourism Management, 2015,47:286-302.

[12] Gu J, Lee S, Suh Y. Determinants of behavioral intention to mobile banking[J]. Expert Systems with Applications, 2009,36(9):11605-11616.

[13]Wu Ruilin. Carlo Monte simulation of convergence problem in structural equation modeling[J]. Statistics and decision, 2010(06):32-34.ng for example loyalty or something else. 